УДК 637.514.5.619:616-91:614:636.4

(C) 2013

Коцюмбас Г. І., доктор ветеринарних наук, професор

Львівський національний університет ветеринарної медицини та біотехнологій імені С. З. Гжицького

Щебентовська О. М., кандидат ветеринарних наук,

П'ятничко О. М., кандидат сільськогосподарських наук,

Коляда Х. О., молодший науковий співробітник

Державний науково-дослідний контрольний інститут ветеринарних препаратів

та кормових добавок, м. Львів

\title{
ДИНАМІКА СТРУКТУРНИХ ЗМІН ГРУДНИХ М'ЯЗІВ КУРЕЙ-БРОЙЛЕРІВ НА РАННІХ ТЕРМІНАХ ПІСЛЯ ЗАБОЮ
}

\section{Рецензент - доктор біологічних наук, професор О. Г. Малик}

\begin{abstract}
Представлена динаміка морфологічних змін грудних м'язів курей після забою. Досліджено терміни розвитку посмертного задубіння та структурні зміни м'язової тканини у прочесі дозрівання м'яса курей. Встановлено, щуо процес автолізу білої групи м'язів відбувається поступово, проте розвивається досить швидко. Вже через 4 години після забою курей-бройлерів зміни, щзо відбуваються у м'язових волокнах, є характерними для початкових ознак автолізу, досягаючи стадії вираженого дозрівання на 24-у годину після забою.
\end{abstract}

Ключові слова: м'ясо птииі, автоліз, сарколема, міофібрили, ядра, мітохондрії, деструкиія.

Постановка проблеми. М'ясо птиці є одним із найпоширеніших видів сировини, що використовується у процесі виробництва напівфабрикатів і готових м'ясних продуктів. На сьогоднішній день практично відсутні дані про структурні зміни м'язової тканини у процесі дозрівання м'яса птиці й терміни розвитку в м'ясі курей посмертного задубіння. Відомо, що м'язи в стані посмертного задубіння є жорсткими, 3 поганими технологічними характеристиками, низькими вологоутримуючими властивостями [1-3].

Аналіз останніх джерел та публікацій, у яких започатковано розв'язання проблеми. У процесі дозрівання м'язової тканини змінюються не лише хімічні та фізичні властивості, але й відбуваються морфологічні та ультраструктурні зміни, які варіюються залежно від стадії автолізу [4-6]. Розуміння динаміки структурних змін у м'язовій тканині курей у процесі автолізу дасть змогу ефективніше його використовувати, особливо на ранніх термінах після забою тварин.

Метою нашої роботи було вивчити морфологічні зміни грудної групи м'язів курей у процесі автолізу.

Завдання: дослідити терміни розвитку посмертного задубіння та структурні зміни м'язової тканини у процесі дозрівання м'яса курей.

Матеріали i методи дослідженнь. Для вивчення змін грудної групи м'язів курей у процесі автолізу відбирали шматочки парного м'яса та м'яса через 15 хв, 1, 2, 4, 12 і 24 години після забою. Для вивчення структурних змін м'язових волокон у процесі автолізу застосовували гістологічні та електронно-мікроскопічні дослідження. Для електронно-мікроскопічного дослідження матеріал фіксували упродовж двох годин у $1,5 \%$ розчині глютарового альдегіду в 0,2 молярному какодилатному буфері $(\mathrm{pH}-7,2)$. Зразки промивали у двох порціях буфера й дофіксовували в $1,5 \%$ розчині окису осмію $\left(\mathrm{OsO}_{4}\right)$. Після відмивання, дегідратації в зростаючих концентраціях етилового спирту контрастували уранілацетатом і заключали в епоксидну смолу - Epon812. Ультратонкі зрізи контрастували уранілацетатом і цитратом свинцю. Зразки переглядали й фотографували в електронно-трансмісійному мікроскопі ПЕМ-100. Для гістологічного дослідження шматочки м'яса фіксували в $10 \%$ нейтральному формаліні, зневоднювали й заливали в парафін. Виготовляли гістозрізи, які фарбували гематоксиліном та еозином.

Результати досліджень. За гістологічного дослідження поперечних зрізів грудних м'язів курей через 15 хвилин після забою м'язові волокна були чітко контуровані, саркоплазма однорідно забарвлена, під сарколемою добре проглядалися темно-сині, видовжено-овальної форми ядра. За допомогою ультраструктурного дослідження м'язової тканини грудних м'язів через 15 хвилин після забою птиці виявляли, що ступінь скорочення актоміозинового білкового апарату варіюється як у різних ділянках м'язів, так і в різних пучках м'язових волокон (рис. 1). 


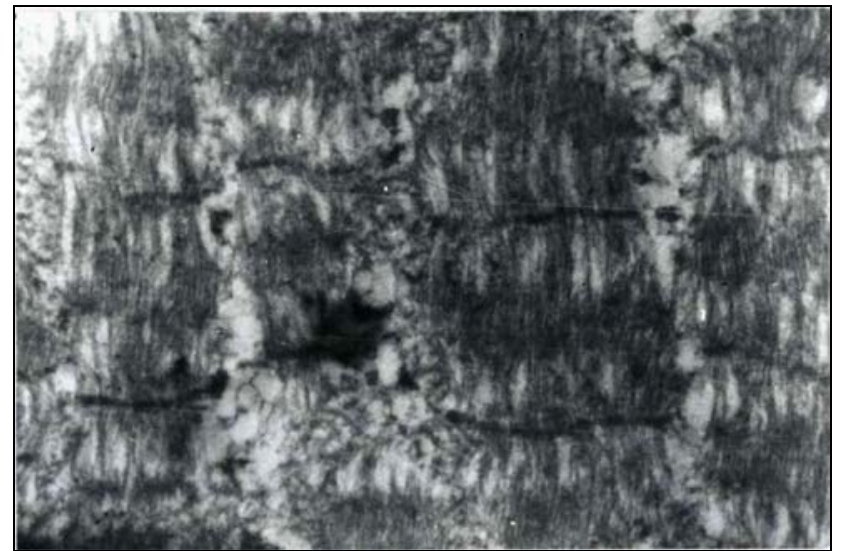

Рис. 1. Ультраструктура грудного м'яза через 15 хвилин після забою, $\mathrm{x} 15000$

Поряд із розслабленими м'язовими волокнами виявляли й сильно скорочені. Між пучками міофібрил скорочувального актоміозинового комплексу і під сарколемою розміщувалися мітохондрії овальної та округлої форм із дещо розрихленими кристами (рис. 2).

У ділянках між міофібрилами чітко проглядалися канальці ендоплазматичного ретикулума. Ядра м'язових волокон були з чіткою, але дещо ввігнутою каріолемою, біля якої концентрувався хроматин. За гістологічного дослідження курячих м'язів через 1 годину після забою виявляли, що більшість м'язових волокон - хвилястої форми, поперечна посмугованість добре виражена. Ядра гіперхромні, овальної форми, розміщуються по всьому об'єму м'язового волокна (рис. 3).

За ультраструктурного дослідження грудних м'язів курей через 1 годину після забою виявляли м'язові волокна на різних стадіях розвитку посмертних змін. Контури каріолеми збережені. Хроматин рівномірно розміщений по периметру

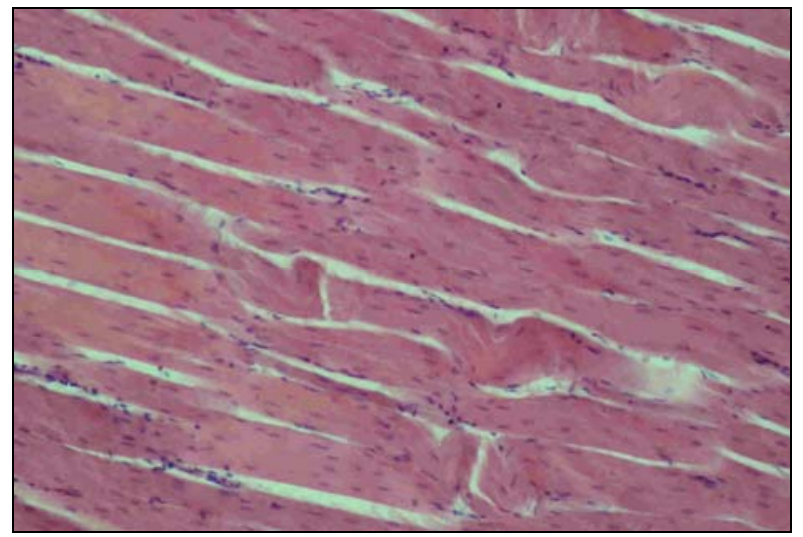

Рис. 3. Структура волокон грудних м'язів курей через 1 год після забою.

Гематоксилін та еозин. Ок. 10, об. 20

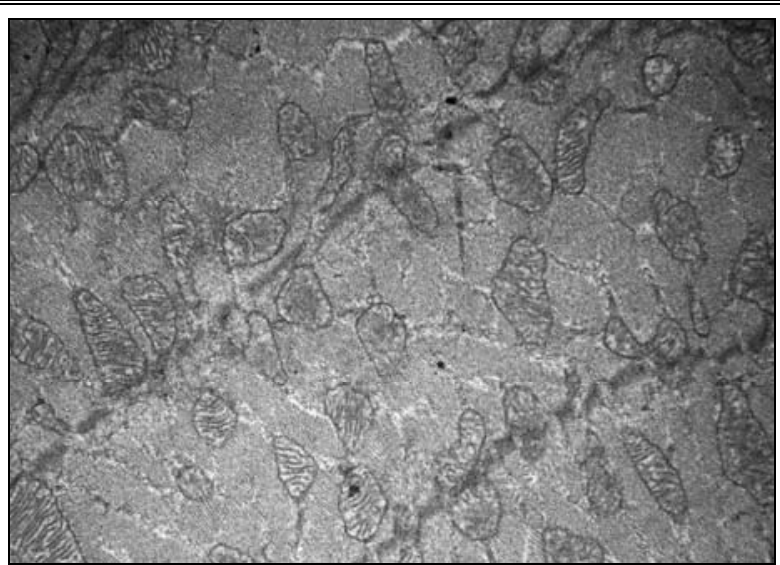

Рис. 2. Мітохондрії з дещо розрихленими кристами через 15 хвилин після забою птиці, $\mathrm{x} 10000$

ядра й не формує виражених скупчень біля каріолеми. Збільшення часу витримки грудного м'яза до однієї години після забою призводить до вираженіших змін актоміозинового комплексу, характеризується помірним скороченням саркомерів і загальним зменшенням їх довжини (рис. 4).

Світлооптично через дві години після забою тварин переважна більшість м'язових волокон звивисті, з добре вираженою поперечною смугастістю. В окремих м'язових волокнах з'являються мікротріщини й деструктивні зміни в ділянках розривів сарколеми. Ультраструктурно ядра м'язових волокон чітко проглядаються, цілісність каріолеми зберігається, хроматин ядра не фрагментується, проте з'являються мітохондрії з пошкодженими зовнішніми мембранами та фрагментованими кристами. Через чотири години після забою та охолодження грудної групи м'язів актоміозиновий комплекс набрякає, порушується цілісність сарколеми. Межі між окремими м'язовими волокнами чітко диференціюються,

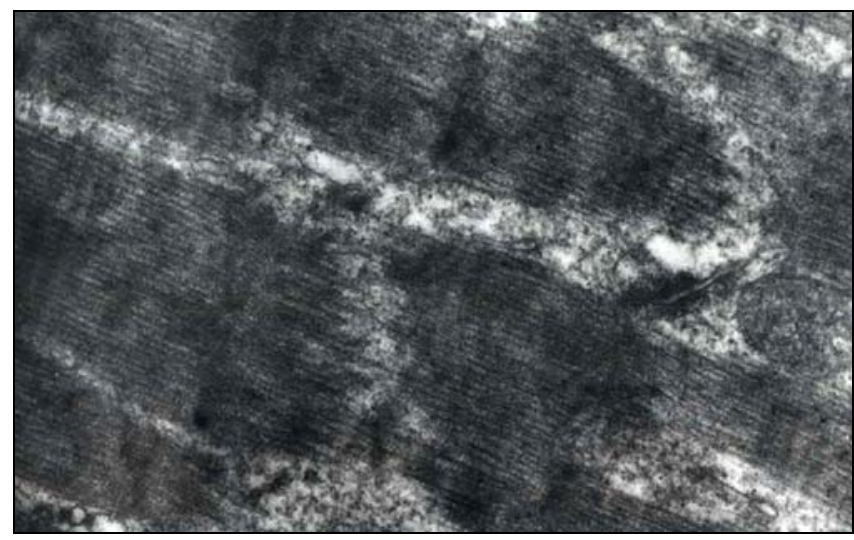

Рис. 4. Ультраструктура м'язового волокна через 1 год після забою, $\mathbf{x} 15000$ 


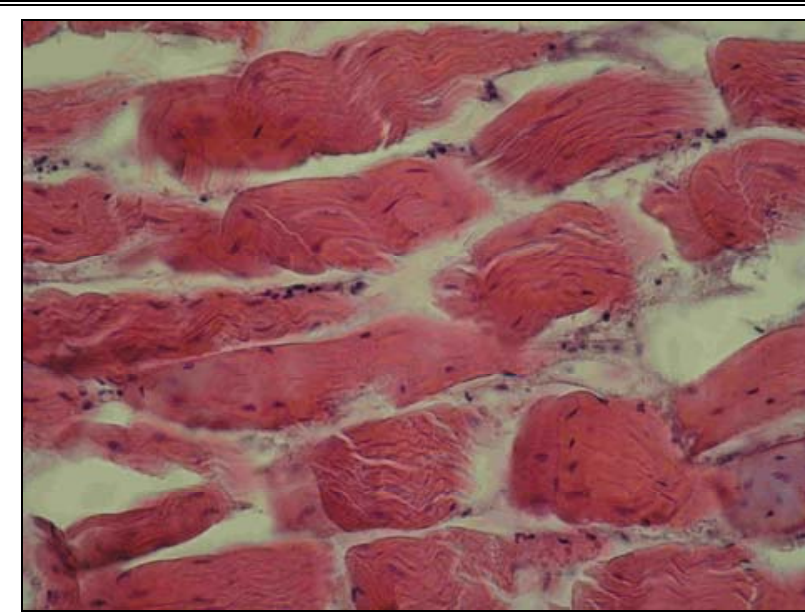

Рис. 5. Структура волокон грудних м'язів курей через 4 год після забою. Поперечні тріщини та розрив м'язових волокон. Гематоксилін та еозин. Ок. 10, об. 40

проте збільшується кількість поперечних тріщин і розривів (рис. 5). Триваліше зберігання м'язової тканини спричиняе деструктивні зміни, характерні для відповідної стадії дозрівання м'яса.

У грудних м'язах через 12 годин після зберігання в охолодженому стані виявляємо множинні щілиноподібні порушеннями саркоплазми. Потовщені, але короткі фрагменти м'язових волокон часто розміщуються окремо від основної маси волокон. Клітинні ядра добре проглядаються. За ультраструктурного дослідження виявляли набряклі мітохондрії $з$ просвітленим матриксом $\mathrm{i}$ фрагментованими кристами. Ядра м'язових волокон набубнявілі, а хроматин набував зернистого вигляду (рис. 6).

Гістологічно у м'ясі, що дозрівало протягом 24-х годин в охолодженому стані, розвивалися

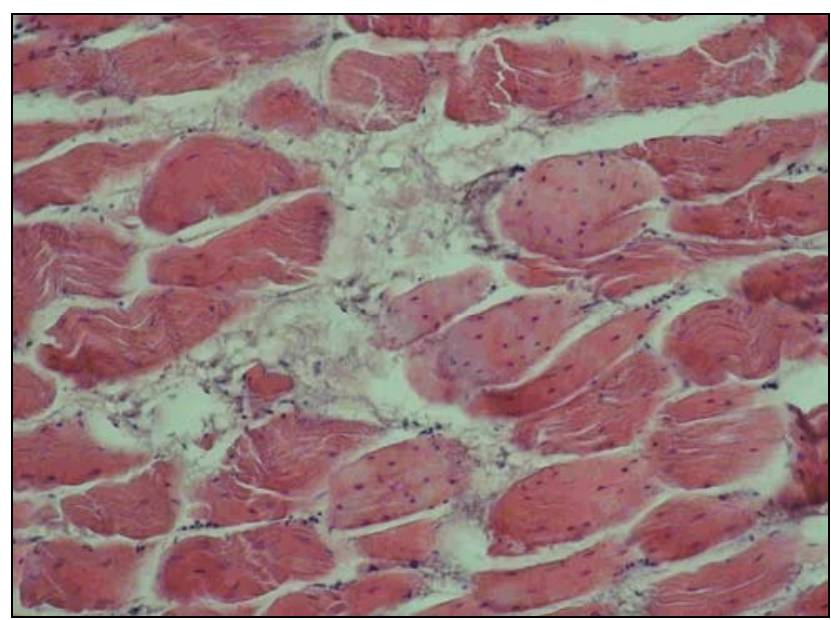

Рис. 7. Структура м'язового волокна через 24 години після забою.

Скупчення зернистої білкової маси.

Гематоксилін та еозин. Ок. 10, об. 40

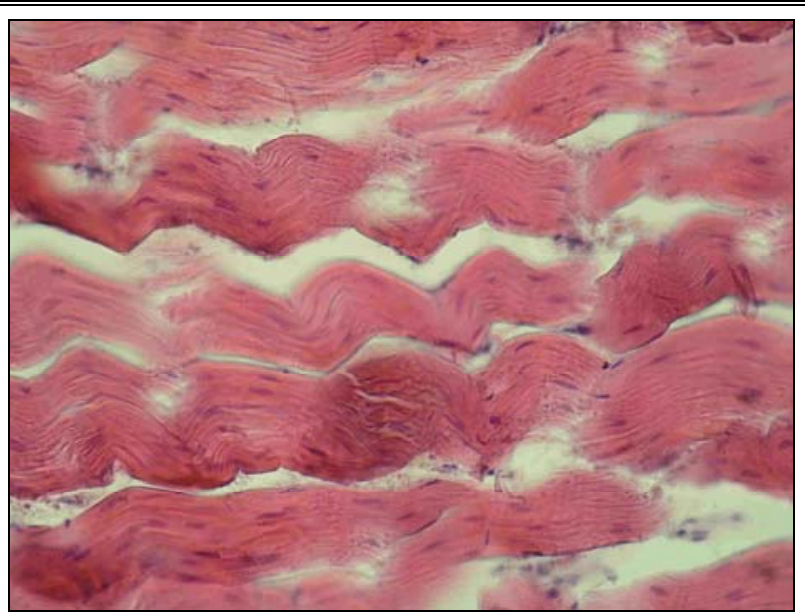

Рис. 6. Структура м'язового волокна грудного м'яза через 12 год після забою.

Тріщини та руйнування саркоплазми.

Гематоксилін та еозин. Ок. 10, об. 40

морфологічні ознаки, характерні для автолізу. Форма окремих м'язових волокон зберігається, хоча переважають деформовані або скручені м'язові волокна вираженою поперечною посмугованістю. У багатьох місцях м'язові волокна 3 поперечними тріщинами і розривами. Ядра клітин овальні або веретеноподібні з вираженим гіперхроматозом. Між елементами м'язової та сполучної тканини відзначали формування дрібнозернистої білкової маси (рис. 7).

Основні ультраструктурні зміни у цей період проявлялися деструкцією ламелярних і фібрилярних елементів м'язових волокон, руйнуванням значної частини клітинних органел, розривом міофібрил і зовнішньої оболонки м'язового волокна - сарколеми (рис. 8).

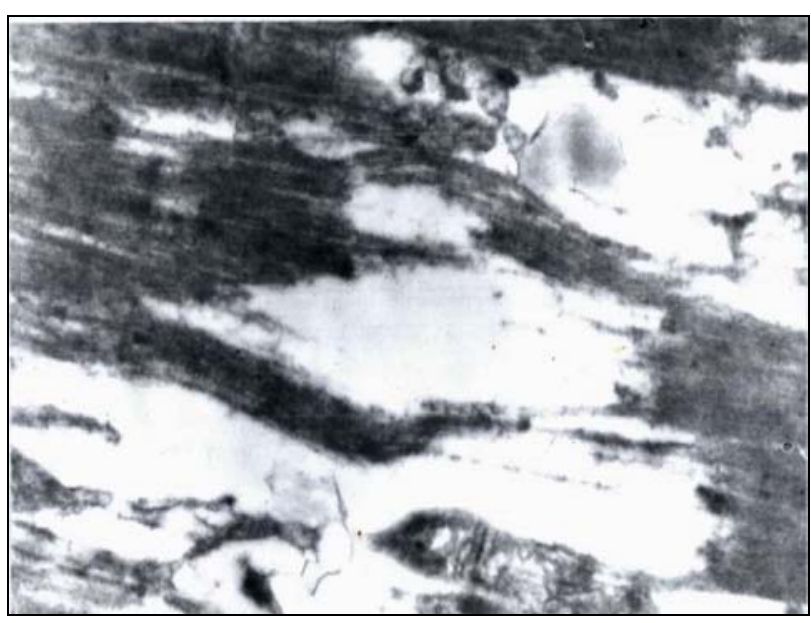

Рис. 8. Ультраструктура м'язового волокна через 24 години після забою птиці, х 15000 
Отже, аналізуючи результати гістологічних та ультраструктурних змін у грудних м'язах через 15 хвилин слід відзначити, що після забою птиці відбуваються етапи переходу від посмертного розслаблення до посмертного заклякання м'язів. Розвиток цих процесів короткий, оскільки поряд iз великою кількістю скорочених м'язових волокон виявляли значну кількість подовжених розслаблених волокон. Через 2 години після забою в грудних м'язах розвивався комплекс структурних змін, характерний для посмертного заклякання, ще проявлялись у вигляді деструктивних процесів: поступово витончувалися нитки актину i, навпаки, набрякали міозину. Вже через 24 години після забою птиці в грудних м'язах виявляли характерні ознаки процесу автолізу. Деструктивні зміни охоплювали значну кількість елементів м'язової тканини і поширювались як на ламелярні, так і на фібрилярні структури м'язових волокон. Мітохондрії набухали, їх кристи фрагментувались, окремі - руйнувалися. Тріщи-

\section{БІБЛІОГРАФІЯ}

1. Бакаливанова Т., Велинов П., Жиков М. Структурно-механични и микроструктурни изменения на диетични полуфабриката от птиче месо. 31 European meeting of meat reserch workers, Bulgaria. - Sofia, 1984. - 1. - P. 321-325.

2. Бем Р. Микроскопия мяса и сырья животного происхождения / Р. Бем, В. Плева // Пищевая промышленность. - М., 1964. - 336 с.

3. ГОСТ 23481-79. Мясо птицы. Метод гистологического анализа. - М. : Госстандарт, 1979. ни м'язових волокон, розриви та фрагментація спричиняли вихід вмісту клітин у міжклітинний простір. Під дією гідролітичних ферментів формувалися, видимі у світловий мікроскоп, зернисті маси. Тривале зберігання м'яса сприяло активнішому розвитку автолітичних процесів, які охоплювали значну кількість м'язових волокон.

Висновок. На ранніх строках після забою курей-бройлерів процес автолізу білої групи м'язів відбувається не одномоментно, хоча розвивається досить швидко, досягаючи стадії вираженого дозрівання вже через 24 години після забою птиці. Однак, слід відзначити, що вже на четверту годину після забою курей-бройлерів зміни, що відбуваються у м'язових волокнах, є характерними для початкових ознак автолізу. Це свідчить про можливе використання такого м'яса для подальшої технологічної обробки, скорочуючи терміни і технологічні цикли в процесі виготовлення м’ясної продукції.

4. Hayden A. R. Detection of chiken flesch in beef sausages // J. Food Sei., 1977. - 42. - P. 1189-1192. 5. Liu A., Nishimura T., Takahashi K. Structural weakening of intramuscular connective tissue during post mortem ageing of chicken semitendinosus muscle // Meat science, 1995. - 39, 1. - P. 135-142. 6. Mikami M., Whiting A.H. Degradation of myofibrils from rabbit, chicken and beef by cathepsin and lysosomal lysates // Meat Science, 1987. - 21, 2. P. 81-97. 